\title{
Reflections on the Reform of Electrical Automation Course in the Transformation Process of General Undergraduate Colleges and Universities
}

\author{
Pengcheng Chen ${ }^{1, \text { a }}$ \\ ${ }^{1}$ School of Automation and Electrical Engineering, Linyi University, linyi, shandong, 276005, china \\ aemail: 765321088@qq.com
}

Keywords: Electrical Engineering and Automation; Teaching Courses; Problems; Reform Countermeasures

\begin{abstract}
In recent years, the demand for the application of undergraduate talents gradually increase with the continuous development of the national economy and science and technology. As an application-oriented specialty for the electrical engineering and automation, the talents training is one of the teaching tasks and objective for the universities and colleges. This paper has discussed in detail the main problems and relevant reform countermeasures in the teaching of the electrical engineering and automation, which provides a reference for the later work.
\end{abstract}

\section{Introduction}

In Shandong Province, Electrical engineering and automation in the universities and colleges is one of the important branches in the mechanical and electrical system, which is also an application of professional courses. With the increasing need for the technical talents in the electrical engineering and automation, the shortcomings of traditional courses stand out, and the reform of teaching methods in the electrical engineering and automation turns to be important.

\section{Analysis of the Main Problems in the Teaching of Electrical Engineering and Automation}

\section{Simple teaching method}

The traditional teaching method in the courses of the electrical engineering and automation is taught by the dictation. The teacher-oriented role has not been played effectively with the lack of students' participation. With the inculcation methods, the students cannot effectively grasp the essence of the content while the students' thinking is bounded. The atmosphere of teaching is always boring so that students' enthusiasm and interest of learning cannot be inspired, resulting in the decreasing quality of the teaching of the course.

\section{Lack of experimental teaching}

For teachers, there is lack of the practice training for students provided by teachers, and there is no effective arrangement for practical training with the courses. For schools, there is lack of capital investment for the practice base and the number of places. The number of laboratory equipment cannot meet the actual needs of students. Instruments and equipment models are not updated in time, which results in that students cannot get in touch with the new operating techniques. All above cannot meet the requirements of the society.

\section{Backward teaching method}

Teachers play significant roles in the course teaching while their own teaching ability and level have a direct impact on the quality of curriculum teaching. At present, The teaching methods of some of them are traditional, which cannot keep up with the progress of the times. Technologies such as multimedia teaching, computer teaching technology etc. are not effectively used. Some teachers lack the awareness of the operation of teaching equipment, which leads to their incompetence.

\section{More teaching contents and less teaching time}

The course of the electrical engineering and automation is an application subject with theory and practice, which covers a wide range of disciplines and techniques. In recent years, some teaching materials have been written too casual, which did not consider the capacity of students, resulting in 
the fact that the students cannot effectively grasp the content of teaching materials. Meanwhile, the teachers cannot keep up with the progress of teaching, resulting in unstable teaching progress.

\section{The Basis, Accordance and Principle of the Course Optimization in Electrical Engineering and Automation}

\section{The basis of understanding the course system}

It is not an issue to construct the course system itself, which embodies the discipline system as the main line of knowledge system. However, we must realize that the reality of the students is not good in the grasp of abstract thinking. Students are not good at the symbolic systems for logical thinking, using symbolic systems to organize concepts or to carry out the results with concepts to organize the principle and theory.

\section{The accordance of the course optimization}

The policy of the party and state education is the general requirements and the accordance for the course optimization. Talent training is to select and prepare the course of the fundamental basis. The horizontal and vertical structure of the course category are determined by the quality structure and logical structure of the training target. The development trend of science and technology promotes the continuous reform of course structure. At the same time, the accordance for evaluating the rationality of the course is whether it can meet the needs of employment of the students.

\section{The principle of the course optimization}

The course optimization should be based on the goal of talents training. The course should take into account the needs of social development, taking full account the knowledge and ability of students to cultivate, dealing with the relationship between generalists and professionals to meet the needs of students. The course is in line with the laws of teaching and the law of comprehensive development of students, reflecting the new achievements of modern science and technology.

\section{Reform and Exploration of Teaching Methods in Electrical Engineering and Automation}

\section{The course system pays attention to cultivating the ability of employment}

Modern course system in the electrical engineering and automation should regards the ability of employment as the core, and highlight the work process in the course framework of the status of main line. A combination of engineering and learning system should be established according to the actual work needs to organize the course. The development of course system should conduct a comprehensive understanding, which include the system design, installation, commissioning, operation, maintenance etc. The specific course system is set according to the e training objectives in the electrical engineering and automation.

\section{The course settings are in accordance with the working tasks}

The courses in the electrical engineering and automation must be set in accordance with the working tasks and the employment needs, which aims to achieve employment-oriented training objectives. The course content can meet the knowledge and skills required for the job or multi-post conversion. The course embodies the concept of "theory as the practical service" and can help to cultivate students' basic ability to have knowledge of internalization, migration and continuing learning. Course content should consider its dynamic and forward-looking characteristics, which will continue to adapt to the development trend of Chinese automation industry.

\section{The application of modern technology}

For teachers, they should get rid of the traditional teaching shackles, readjust their teaching ideas, improve their teaching methods, so that it is more adapted to the modern social environment. For example, the teacher can apply the multi-media teaching technology to the teaching method, the course content and the concept of the courseware production and the lesson plans, so as to put the theory of knowledge into a specific image presentation, which can deepen the understanding of students. In the process of making e-lesson plans, teachers can be divided according to the content of the course materials system, so as to establish a sound and clear course system and get rid of the shackles of teaching materials. For some of the key points, teachers can make the relevant PPT 
courseware. The application of PPT courseware has made a breakthrough in the traditional blackboard teaching, greatly saving the teacher's writing time and improve the efficiency of teaching.

\section{The teaching method is adjusted to promote the participation of students}

In the course of teaching, teachers play their oriented position to promote the participation of students. Teachers can guide students to collect relevant information and materials, and develop the non-intellectual factors. Teachers take the use of multi-media technology for students to create a fun and vivid learning atmosphere and improve students' independent thinking and inquiry ability to strengthen the interaction between students, which aims to achieve the mutual improvement and mutual inspiration. Teachers strengthen the guidance, observation and supervision of students in the direction of thinking. Students can communicate and interact patiently, which enrich the students' learning time.

\section{The application of simulation technology}

Teachers can use WorkBench and other simulation software to help students in the experimental study through the method of circuit connection, and the relevant parameter settings. Students are not only familiar with the application of computer software technology, experimental data settings and circuit connections, but also get the in-depth understanding. Students can be clear to understand in the actual experimental inquiry on the experimental steps and related points, which helps to reduce the problem of experimental process and improve the student's experimental success rate. In addition, the application of simulation software allows students to fulfill the innovation and subjective initiative and thus improves students' learning ability.

The training is carried out to strengthen the ability of teachers with modern teaching methods

It is important for teachers to be willing to use modern teaching methods. Teachers should be trained to carry out modern teaching methods, so that teachers understand the use of modern teaching methods and master the use of modern teaching techniques.

(1) To organize the theory study. Unify the ideas of all teachers, raise awareness and stimulate the use of modern teaching methods within the driving force.

(2) To carry out the teaching demonstration. Organize teachers to participate in demonstration activities of the modern teaching means, and strive to demonstrate that teachers master the use of teaching techniques.

(3) To carry out the development activities. Organize the multi-media teaching technology training courses, and actively encourage teachers to develop the courseware so as to improve the use of modern teaching methods.

\section{Conclusions}

In conclusion, the universities and colleges should strengthen the overall quality of students, practical ability and innovative spirit of training to improve the students' social competitiveness and quality of education. In addition, schools should adhere to the concept of running the market of employment followed by social development and market demand to develop in line with the talents in the electrical engineer and automation by the adjustment of the course system.

\section{References}

[1] Zhang L, Zheng G, Chen Z, et al. Discussions of the Mathematics Teaching Reform in Normal Universities under "New Curriculum Standard"[C]// International Conference on Industrial Mechatronics and Automation. IEEE, 2010:577-580.

[2] Yin B. Education Reform of National Colleges and Universities In the Background of New Curriculum[J]. Journal of Hubei Institute for Nationalities, 2003.

[3] Miao S H, Yan B, University Q N. An Investigation of the Normal Students' Conception of Teaching under of New Curriculum Reform_-Based on the Survey of Normal Students of 
Universities in Shandong[J]. Contemporary Teacher Education, 2014.

[4] Mei L I. Research on Assessment Method Reform concerning High School English Teaching under the Background of New Curriculum Reform[J]. Journal of Sichuan College of Education, 2012.

[5] Jun-Feng L I. On the New Teaching Practice Mode of Geography Department in Normal Universities in the Background of Curriculum Reform[J]. Journal of Anhui Normal University, 2009. 